\title{
Effects of tectonically induced fabrics on geomechanical properties of rocks, NW Pakistan
}

\author{
Asghar Ali $^{1} \cdot$ Saddam Hussain ${ }^{1} \cdot$ Shehzad Khan $^{1} \cdot$ Awal Sher Khan $^{1} \cdot$ Sohail Mabood ${ }^{1} \cdot$ Rafique Ahmad $^{2}$
}

Received: 6 July 2018 / Accepted: 26 May 2020 / Published online: 3 June 2020

(C) The Author(s) 2020

\begin{abstract}
The Chakdara Granitic Gneisses (CGG) of the Indian plate and Kamila Amphibolite of the Kohistan Island Arc (KIA) along the Main Mantle Thrust (MMT) in Shigo Kas, Talash Dir Lower, indicate that tectonically induced foliations and lineations strongly affected the geomechanical properties of these rocks. The earlier $\mathrm{S}_{1}$ crenulated cleavages are well preserved in the microlithon of a well-developed ENE-WSW trending $\mathrm{S}_{2}$ crenulation cleavage. The pervasive $\mathrm{S}_{2}$ foliations, $\mathrm{D}_{2}$ fold axes, and $\mathrm{L}_{2}^{2}$ lineations are induced by NNW-SSE horizontal bulk shortening. The core samples obtained parallel and perpendicular to the main ENE-WSW trending $\mathrm{S}_{2}$ and $\mathrm{L}_{2}{ }_{2}$ have higher and lower uniaxial compressive strength (UCS) values, respectively. The UCS and uniaxial tensile strength (UTS) average values of four core samples obtained parallel and perpendicular to the main $\mathrm{S}_{2}$ are $51.8 \mathrm{MPa}$ and 12.21 MPa versus 45.65 MPa and 12.45 MPa, respectively. Core samples from the weakly foliated S-2 specimen shows little variation in the UCS and UTS values. The variation in the UCS values in the core samples cut perpendicular and parallel to the main tectonic fabric has been controlled by micro-shear zones at the contact zones of crenulated and crenulation cleavages and sigmoidal mica fish. The UCS values are higher in the core samples parallel to the pervasive $\mathrm{S}_{2}$ and $\mathrm{L}_{2}{ }_{2}$ because the parallel shear on the sigmoidal crenulated cleavages in microlithon of the $\mathrm{S}_{2}$ and $\mathrm{S}_{2}$ mica fish counterbalance the parallel external applied load. However, the UCS values decrease in the core samples that were cut perpendicular to the pervasive $\mathrm{S}_{2}$ and $\mathrm{L}_{2}{ }_{2}$ because the perpendicular shear on the sigmoidal crenulated cleavages in microlithon of the $\mathrm{S}_{2}$ and $\mathrm{S}_{2}$ mica fish enhances the external applied load, which lead to the failure of core samples.
\end{abstract}

Keywords MMT $\cdot$ Microscopic to mesoscopic structures $\cdot$ Geomechanical properties $\cdot$ Mica fish

\section{Introduction}

Geomechanical properties play important role to predict rocks strength and failure under an applied load for safe engineering purposes. Millions of years deformations, metamorphism, tectonic stresses, and thermal processes associated with crust thickening induce anisotropies in rocks in the form of foliations, lineations, fractures, and shears that affect strength behavior of rocks (Hudson and Harrison 1997; Milnes et al. 2006). Determining geomechanical properties without understanding pre-existing anisotropies at all scale of observations

Asghar Ali

asghar.ali@uop.edu.pk

1 Department of Geology, University of Peshawar, Peshawar, Pakistan

2 Department of Geology, Bacha Khan University, Charsadda, Pakistan may lead to unrealistic rock strength calculation (Ramamurthy et al. 1993; Hudson and Cosgrove 1997). Tectonically induced penetrative foliations, mineral lineations, mica fish, SC fabrics, mantle porphyroclast, and shear zones can be used to derive movement of planes along which a rock can potentially collapse during or after construction (Lister and Snoke 1984; Priest 1993; Hudson and Cosgrove 1997; Passchier and Trouw 2005; Chamine et al. 2013; Barton and Quadros 2015; Watkins et al. 2015). Similarly, the planes, which truncate asymmetric crenulated cleavages (S-fabric) in the microlithon against the main crenulation cleavage (C-fabric), can provide additional shear planes for applied loaded stresses. These tectonically induced anisotropies in deformed rocks can potentially affect the engineering characteristics of rocks (Duan and Kwok 2015). Therefore, it is critical to take into account the pattern of metamorphic fabrics, which distinctly exhibit coordinated geometric planes of weakness in tectonically deformed rocks (cf. Miskovsky et al. 2004; Punturo et al. 2014). Most of the times less attention is paid to study 
tectonically induced fabrics, mineral lineations, and intersection lineations in the rocks that eventually are used in construction and as bedrocks. These structures that are produced as a result of multiple deformations could affect mechanical strength of rocks, which make construction designs more complex and elaborative (Milnes 2006). Indian plate and KIA collision induced multiple penetrative foliations and lineations at all scale of observations in the rocks exposed south and north of the MMT (DiPietro et al. 2008; Ali et al. 2016). This research insight into the affects of tectonically induced geometric structures on rocks compressive and tensile strengths and thus provides a better understanding of the effect of tectonic fabrics on the engineering properties of a rock.

\section{Regional geology}

The MMT formed as a result of the Indian plate collision with the KIA $\sim 60$ to $40 \mathrm{Ma}$ (Fig. 1; Yin 2006). The KIA is formed as a result of intra-oceanic subduction of the Neo-Tethys in the Cretaceous. The MMT mélange zone is the western continuation of the Indus Tsangpo Suture Zone, which is comprised of deformed and metamorphosed northernmost and southernmost marginal rocks of the Indian plate and KIA, respectively (Fig. 1; DiPietro et al. 2008 and references therein). Four penetrative tectonic fabrics have been established in the northernmost rocks of the Indian plate (DiPietro et al. 2008; Ali et al. 2016). NW$\mathrm{SE}$ trending $\mathrm{D}_{1}$ structures are mostly preserved in the microlithons as crenulated cleavages or in the garnet porphyroblasts. At outcrop scale $\mathrm{D}_{1}$ are transposed by NESW to ENE-WSW trending $\mathrm{D}_{2}$ structures, which is the most dominant fabric of the northernmost Indian plate. The $\mathrm{D}_{2}$ structures are later overprinted by $\mathrm{D}_{3}$ structures that also resulted into regional-scale domal and syntaxial structures. $\mathrm{D}_{3}$ associated fabric is counterclockwise rotated by $\mathrm{D}_{4}$ tectonic event (Ali et al. 2016). Chlorite replacement by biotite in the main $S_{2}$ crenulation cleavage domain indicates prograde metamorphic conditions associated with the $\mathrm{D}_{2}$. It has been interpreted that the garnet growth predated $\mathrm{D}_{2}, \mathrm{D}_{3}$, and $\mathrm{D}_{4}$ tectonic events because the main $\mathrm{S}_{2}$ fabric is wrapped around the garnet porphyroblasts (Ali et al. 2016).

The study area comprises MMT hanging and foot walls (Fig. 1). The hanging wall comprises the Indus suture zone and Kamila Amphibolite, whereas the foot wall consists of the
Fig. 1 Detailed regional tectonic framework and stratigraphic map of the northern Pakistan (after DiPietro and Pogue 2004)

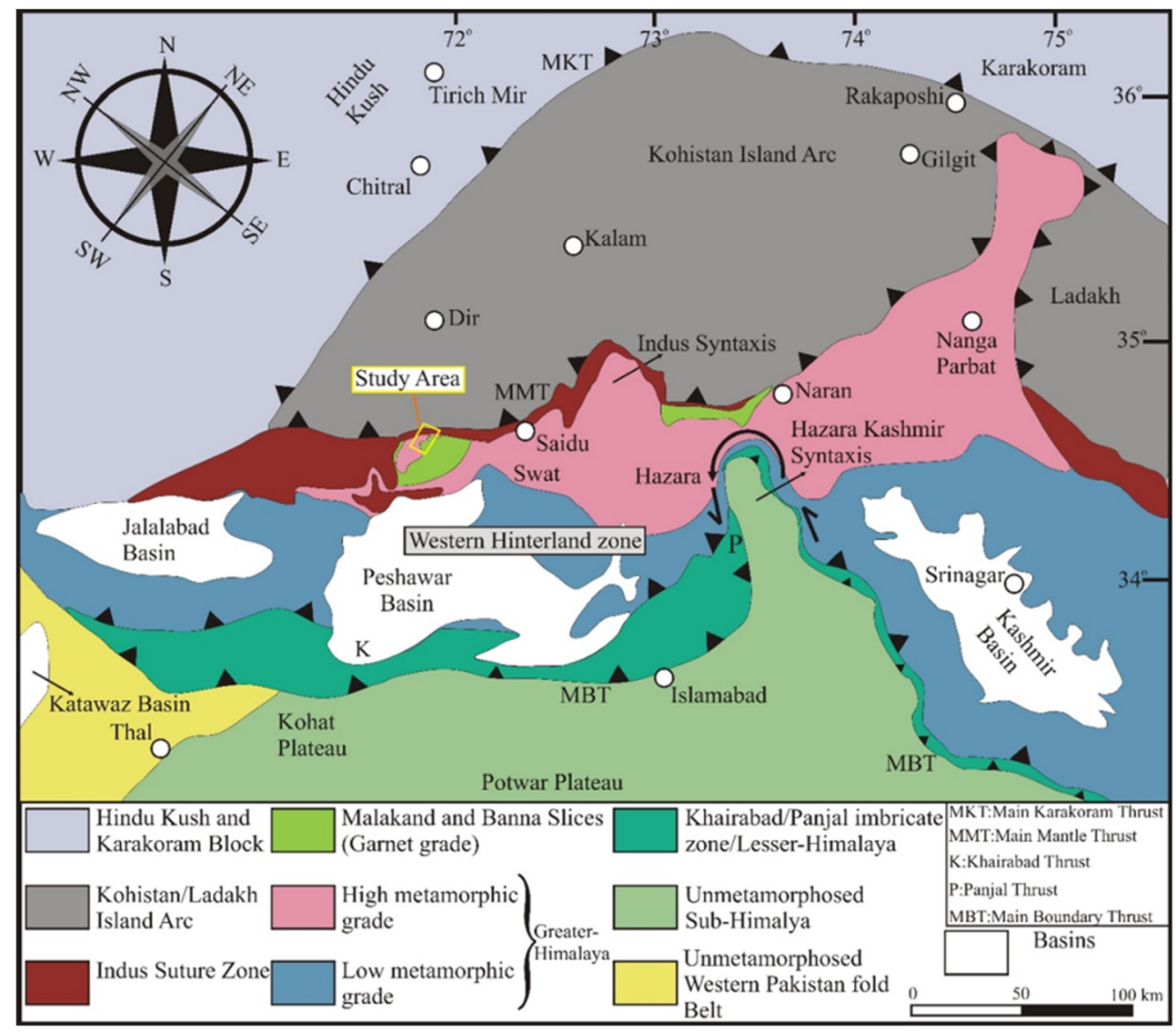


Cambrian to Ordovician CGG (Kazmi and Jan 1997) and Permian to Late Mesozoic Alpurai Group metasediments of the Indian plate (DiPietro et al. 2008).

\section{Methodology}

Penetrative planar and linear fabrics were measured from the CGG, melange zone, and Kamila Amphibolite exposed north and south of the MMT respectively (Fig. 1). Petrographic and micro-structural analyses were made from 19 oriented samples that were cut parallel to the main crenulation cleavage. Respectively four and one bulk samples were collected from the CGG and Kamila Amphibolite to study the effect of the metamorphic fabric on the mechanical properties of rocks. A total of two core samples perpendicular and parallel to the main tectonic fabric were obtained according to ASTM specification (ASTM D-3976 1986) from each bulk sample to calculate the UTS and UCS. These tests were conducted at the Department of Mining Engineering, University of Engineering and Technology, Peshawar.

\section{Detailed petrographic investigations}

A total of 19 oriented samples were collected from CGG, melange zone, and Kamila Amphibolite exposed north and south of the MMT respectively. These samples were cut parallel and perpendicular to the main crenulation cleavage. Detailed petrographic investigations distinguished granitic gneisses, siliceous chloritized marble, amphibolite, undifferentiated quartz rich foliated rock, and epidote chlorite schist on the basis of mineralogy (Table 1). The granitic gneisses are mainly comprised of quartz, alkali feldspar, plagioclase, biotite, and muscovite with minor garnet and epidote. These rocks are characterized by well-developed cleavage domain (crenulation cleavages/C-fabric) dominated by muscovite, biotite, and stretched quartz grains, and microlithon/Q-domain shows concentrated quartz, feldspar, and plagioclase (Fig. 2ac). Plagioclase and feldspar exhibit sericitization (Figs. 2b, c and $3 \mathrm{a}-\mathrm{d})$. The crenulation cleavage that is defined by elongated biotite and muscovite deflected around the pre-existing feldspar and plagioclase grains (Fig. 3a-d). Intense deformation imparted undulose extinction to quartz grains in all samples. The replacement of feldspar and plagioclase by muscovite indicates retrograde metamorphic conditions in the region. The partitioning of deformation into coaxial and noncoaxial zones around feldspar and plagioclase grains nicely developed strain shadows (Fig. 3c, d). Coarse-grained amphibolite exposed north of the MMT mélange zone mainly consists of amphibole with well-developed epidote and retrograde chlorite. The preferred orientation of elongated amphibole imparted foliation to amphibolite (Fig. 3e). The epidote chlorite schist from the mélange zone comprises mainly epidote, chlorite, and quartz (Fig. 4a-d). The main gneissosity in

Table 1 Detailed visually calculated modal mineralogical classification of granitic gneiss, siliceous chloritized marble, amphibolite, undifferentiated quartz-rich foliated rock, and epidote chlorite schist (mineral abbreviations after Whitney and Evans 2010)

\begin{tabular}{|c|c|c|c|c|c|c|c|c|c|c|c|}
\hline Rock types & Sample. no. & Qz & $\mathrm{Bt}$ & Ms & $\mathrm{Pl}$ & Afs & Amp & Grt & Ep & Chl & $\mathrm{Cal}$ \\
\hline \multirow[t]{15}{*}{ Granitic gneiss } & $\mathrm{S} 1$ & 44 & 15 & 15 & 5 & 20 & - & - & $\sim 1$ & - & - \\
\hline & $\mathrm{S} 2$ & 36 & 20 & 17 & 21 & 6 & - & $<1$ & & - & - \\
\hline & $\mathrm{S} 4$ & 35 & 4 & 24 & 13 & 20 & - & $<1$ & $\sim 1$ & - & - \\
\hline & S5 & 56 & 2 & 7 & 10 & 25 & - & - & - & - & - \\
\hline & S6 & 36 & 22 & 20 & 13 & 9 & - & - & - & - & - \\
\hline & S7 & 40 & 15 & 15 & 10 & 20 & - & - & - & - & - \\
\hline & S8 & 27 & 20 & 30 & 12 & 11 & - & - & - & - & - \\
\hline & S9 & 34 & 25 & 25 & 7 & 9 & - & - & - & - & - \\
\hline & $\mathrm{S} 10$ & 38 & 20 & 12 & 12 & 18 & - & - & - & - & - \\
\hline & $\mathrm{S} 11$ & 40 & 3 & 20 & 7 & 30 & - & - & - & - & - \\
\hline & $\mathrm{S} 12$ & 44 & 25 & 10 & 5 & 16 & - & - & - & - & - \\
\hline & $\mathrm{S} 13$ & 45 & - & 8 & 20 & 25 & - & 2 & - & Traces & - \\
\hline & $\mathrm{S} 15$ & 50 & 13 & 20 & 7 & 5 & - & 5 & - & - & - \\
\hline & $\mathrm{S} 16$ & 45 & - & 20 & 12 & 22 & - & $\sim 1$ & - & - & - \\
\hline & $\mathrm{S} 17$ & 50 & 1 & 15 & 7 & 27 & - & - & - & - & - \\
\hline Siliceous chloritized marble & $\mathrm{S} 18$ & 30 & - & - & - & - & - & - & - & 20 & 50 \\
\hline Amphibolite & S3 (Core) & Traces & - & 1 & - & - & 84 & - & 13 & 2 & - \\
\hline Foliated rock & S19 & Undifferentiated quartz-rich foliated rock & & & & & & & & & \\
\hline Epidote chlorite schist & $\mathrm{S} 20$ & 20 & - & - & - & - & - & - & 45 & 35 & - \\
\hline
\end{tabular}


Fig. 2 a Crenulation cleavage defined by elongated biotite, quartz, and muscovite deflects around the pre-existing feldspar and plagioclase grains. The thin section cut normal to ENE-WSW trending foliation (XPL); $\mathbf{b}$ sericitized plagioclase lying in the microlithon of the well-defined $\mathrm{S}_{2}$ crenulation cleavage, which is defined by elongated muscovite and quartz. S2 sheared around plagioclase phenocrysts. The thin section cut normal to ENE-WSW trending foliation (XPL); $\mathbf{c}$ partially sericitized plagioclase grain in the microlithon of the $\mathrm{S}_{2}$ crenulation cleavage (XPL). The thin section cut parallel to ENE-WSW trending foliation
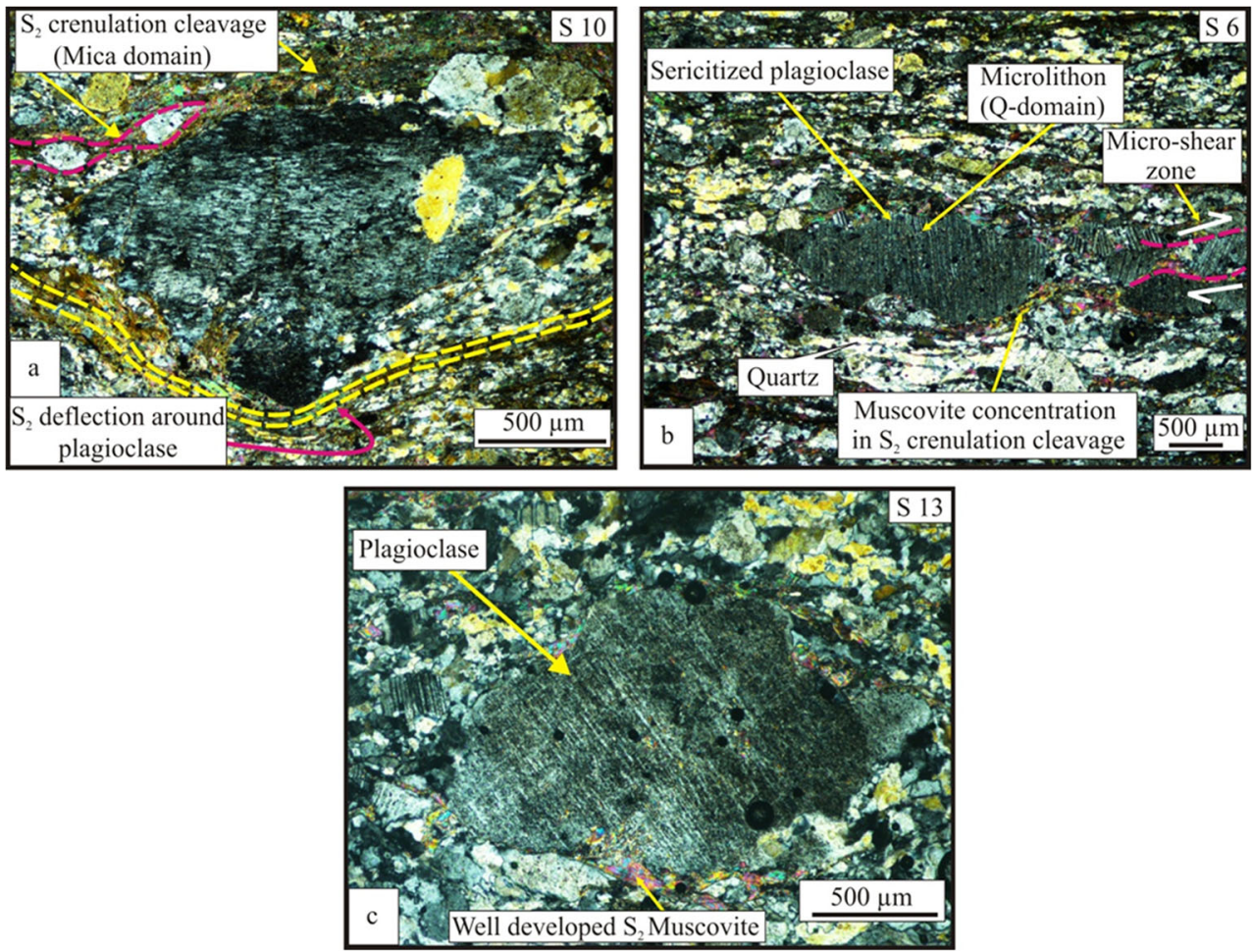

the rock is cut across by a quartzo-feldspathic vein (Fig. 4a). Detailed observation of the specimens from thin section in plane polarized and cross-polarized lights revealed that the larger crystals of epidote with high relief and well-developed cleavages are preferredly oriented (Fig. 4c). Rounded epidote clusters are randomly fractured (Fig. 4b). Mineral rims, fractures, and cleavages are replaced by chlorite (Fig. 4c, d).

\section{Mesoscopic structures}

Multiple deformed rocks of the CGG, melange zone, and Kamila Amphibolite preserved progressive fabric development in the form of $\mathrm{S}_{2}, \mathrm{~L}_{2}{ }_{2}$, and $\mathrm{L}_{2}{ }_{2}$ in the rock matrix and at outcrop. $\mathrm{D}_{2}$-related $\mathrm{S}_{2}$ forms the dominant regional foliation and is ornamented by $\mathrm{L}_{2}{ }_{2}$ mineral stretching lineations (quartz and feldspar) in the CGG (Fig. 5a-d).

A total of 22 measurements of $\mathrm{S}_{2}$ were plotted on the stereo net (Fig. 6a). A total of $15 \mathrm{~L}_{2}^{3}$ intersection lineations are measured, and their plunge directions are plotted on stereo net (Fig. 6b). Intersection lineations are plunging in ENE direction. $\mathrm{L}_{2}^{2}$ mineral stretching lineations data were collected at outcrop and from oriented photographs. A total of 322 ENE-WSW trending $\mathrm{L}_{2}^{2}$ were measured, and their orientation was plotted on rose diagram (Fig. 6c). About 239 and $83 \mathrm{~L}_{2}^{2}$ mineral stretching lineations were measured at outcrop and from oriented photographs, respectively. $\mathrm{All} \mathrm{L}_{2}{ }_{2}$ mineral stretching lineations are parallel to $\mathrm{D}_{2}$ fold axis. A total of
19 vertical thin sections parallel to lineation were prepared to study the mineral elongation lineation at microscopic scale. Microscopically the $S_{2}$ parallel lineations are defined by elongated muscovite, quartz, biotite, and feldspar grains.

\section{Microscopic structures}

Mica fish orientations were measured from oriented thin sections (Fig. $7 \mathrm{a}-\mathrm{f}$ ) in the plane parallel to the stretching lineations. Morphology of mica fish allowed a subdivision into several groups based on orientation of lattice plane and shape. Most of the mica fish lie in the range of sigmoid to lenticular shape with few in the composite shape. Measurement of the angle of long axis of 335 mica fish with main foliation gives a mean value of $22.21^{\circ}$ (Table 2). These mica fish show top-toSSE shear sense south of the MMT.

The sigmoidal quartz grains exhibit similar shape strain shadows and shape preferred orientation to the mica fish. The quartz grains are elongated in shape and contain small recrystallized grains dominantly at the tips of the fish (Fig. $7 \mathrm{~d}, \mathrm{f})$. These fish-like quartz crystals were formed by crystal-plastic deformation (Ten Grotenhuis et al. 2003). This sigmoidal recrystallized quartz fish shows a dextral shear sense (Fig. 7d, f). The presence of mica fish in the microlithon and $\mathrm{C}$-fabric in CGG is defined by the concentration of muscovite, biotite, and stretched quartz to the top of the SSE dextral shear sense (Fig. 3b, c, d). 
Fig. 3 a An elongated feldspar grain in the microlithon of the $\mathrm{S}_{2}$ crenulation cleavage. The crenulation cleavage is concentrated by biotite, muscovite, and elongated quartz. The thin section cut parallel to ENE-WSW trending foliation (XPL); $\mathbf{b} \mathrm{S}_{2}$ deflection around medium sericitized plagioclase grain. $\mathrm{S}_{1}$ crenulated cleavage preserved in low strain region. The thin section cut normal to ENEWSW trending foliation (XPL). $\mathbf{c}$ d The coaxial and non-coaxial zones around the highly sericitized feldspar and plagioclase grains nicely developed the strain shadows. Intensification of $\mathrm{S}_{2}$ around rigid plagioclase and feldspar grains developed strain caps. The thin sections cut parallel to ENE-WSW trending foliation (XPL); (e), twin elongated amphibole (XPL)
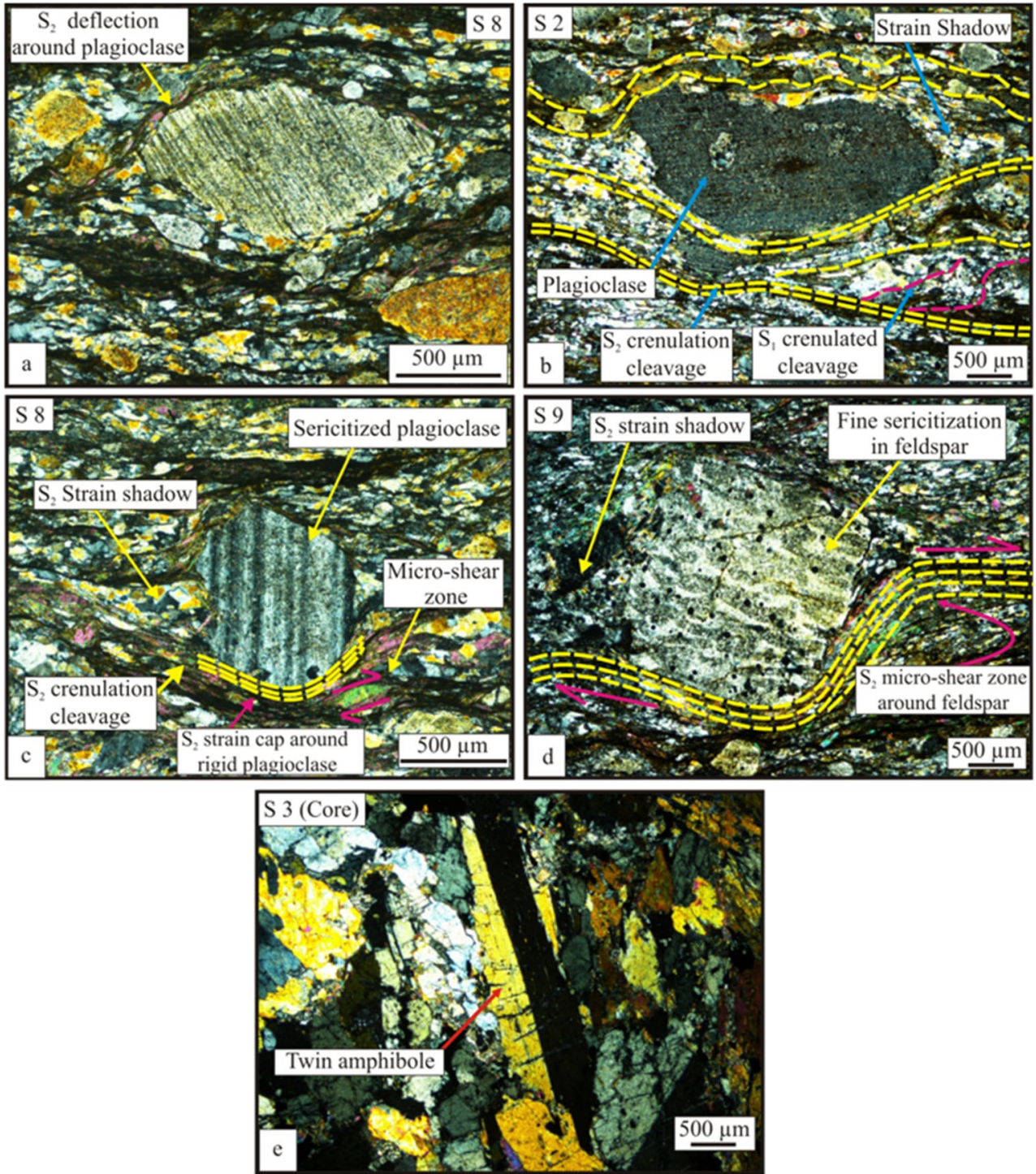

\section{Geomechanical properties}

Based on detailed petrographic observations five bulk samples, four from CGG and one from Kamila Amphibolite, were selected for detailed geomechanical analyses. The presence of foliations and lineations at all scales of observations in these rocks indicates that these structures are pervasively developed in the region. To look into the impact of penetrative fabrics on the strength of rocks the selected bulk samples were cored perpendicular and parallel to the main $\mathrm{S}_{2}$ foliations using core drilling machine housed at the Department of Mining Engineering, University of Engineering and Technology Peshawar. For UCS, foliation parallel and perpendicular cylindrical samples were cut according to ASTM specification (ASTM D-3976 1986). UTS were determined in disc shape samples that were obtained parallel and perpendicular to the main $\mathrm{S}_{2}$ fabric according the ASTM specification (D-3976). These tests were performed at Survey Laboratory, Department of Mining Engineering, University of Engineering, and Technology Peshawar. Porosity, water absorption, and specific gravity of the above cored samples were determined at the Rock Cutting Laboratory, Department of Geology, University of Peshawar.

\section{Strength of the Core samples}

The strength of core samples was determined through UCS (ASM D-7012 2010) and UTS using universal testing machine (UTM). The UTS values were measured by Brazilian method (ASTM D-3967 1986).

\section{Shear strength}

The shear strength was indirectly calculated from UCS and UTS in two-dimensional graphical representations using the Mohr's circle (Fig. 8). The cohesion (c) was determined by 
Fig. 4 a Photomicrograph showing quartzo-feldspathic vein cuts across the main matrix schistosity (XPL); b randomly oriented epidote clusters in the matrix (XPL); c, $\mathbf{d}$ chloritization at the margins and within the fractures/cleavages of epidote crystals (PPL)
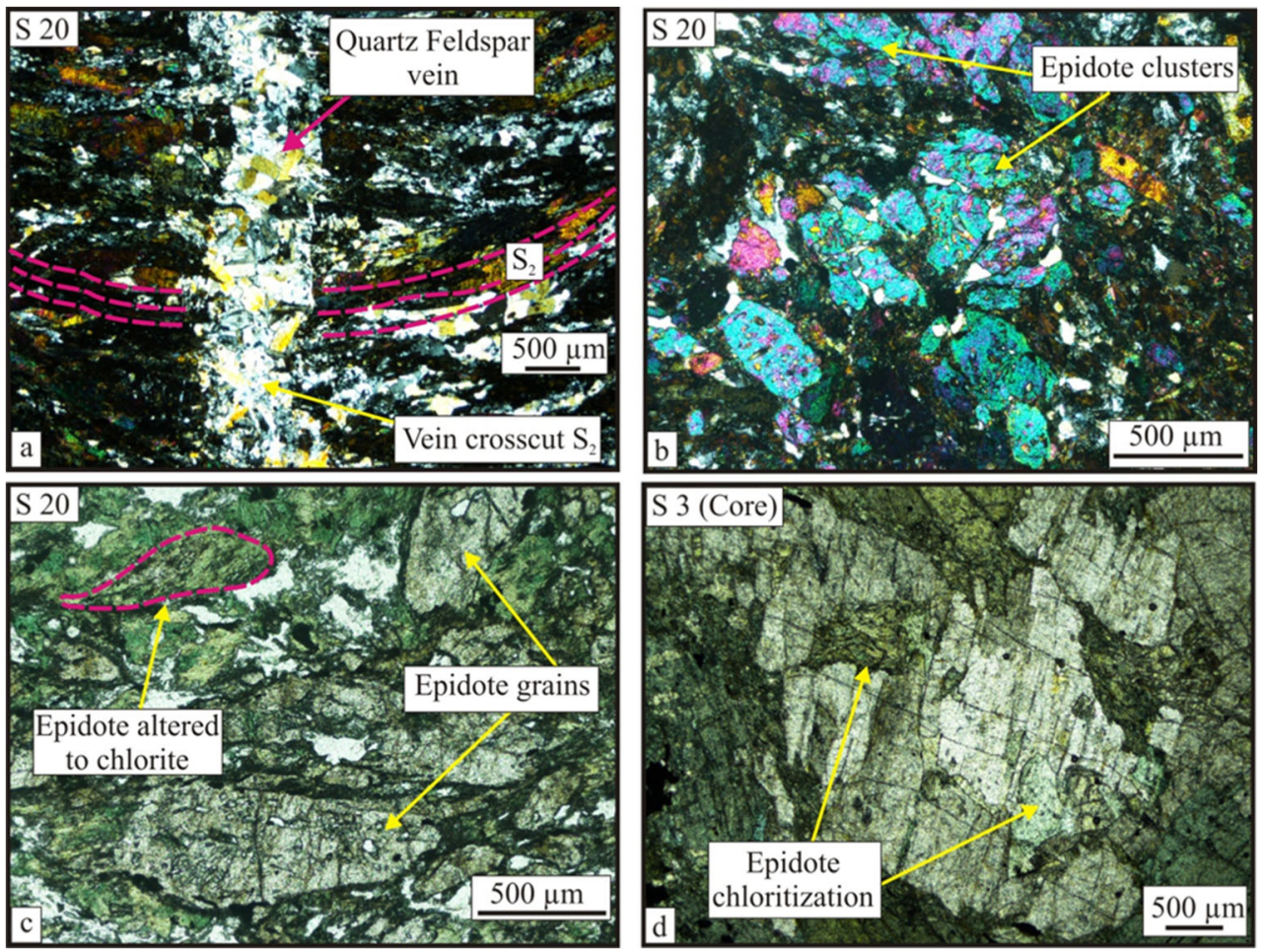

measuring the distance between the points of intersection between $X$ and $Y$ and the point at which the tangent cuts the vertical axis, whereas the maximum shear strength $(\tau)$ was calculated by plotting the failure point along $Y$-axis (Table 3). The angle of internal friction $(\Phi)$ was calculated from the angle of tangent with the $X$-axis (Table 3 ).

\section{Results}

Mesoscopically ENE-WSW trending $\mathrm{S}_{2}$ pervasive foliation and $\mathrm{L}_{2}^{2}$ developed parallel to $\mathrm{D}_{2}$ fold axis (Fig. $6 \mathrm{c}$ ). The $\mathrm{D}_{2}$ tectonic event is overprinted by ENE plunging $\mathrm{L}_{2}^{3}$ intersection lineations (Fig. 6b). The sigmoidal $\mathrm{S}_{1}$ crenulated cleavage
Fig. 5 a, b Oriented field photos showing ENE-WSW trending $\mathrm{D}_{2}$ folds. "b" is the cut section of $\mathrm{D}_{2}$; c $\mathrm{L}_{2}^{3}$ intersection lineations are defined by the intersection of the $\mathrm{S}_{2}$ and weakly developed $\mathrm{S}_{3}$ foliations; $\mathbf{d}$ ENE-WSW trending $\mathrm{L}_{2}^{2}$ lineations defined by stretched quartz and feldspar grains are oriented parallel to the main $\mathrm{S}_{2}$
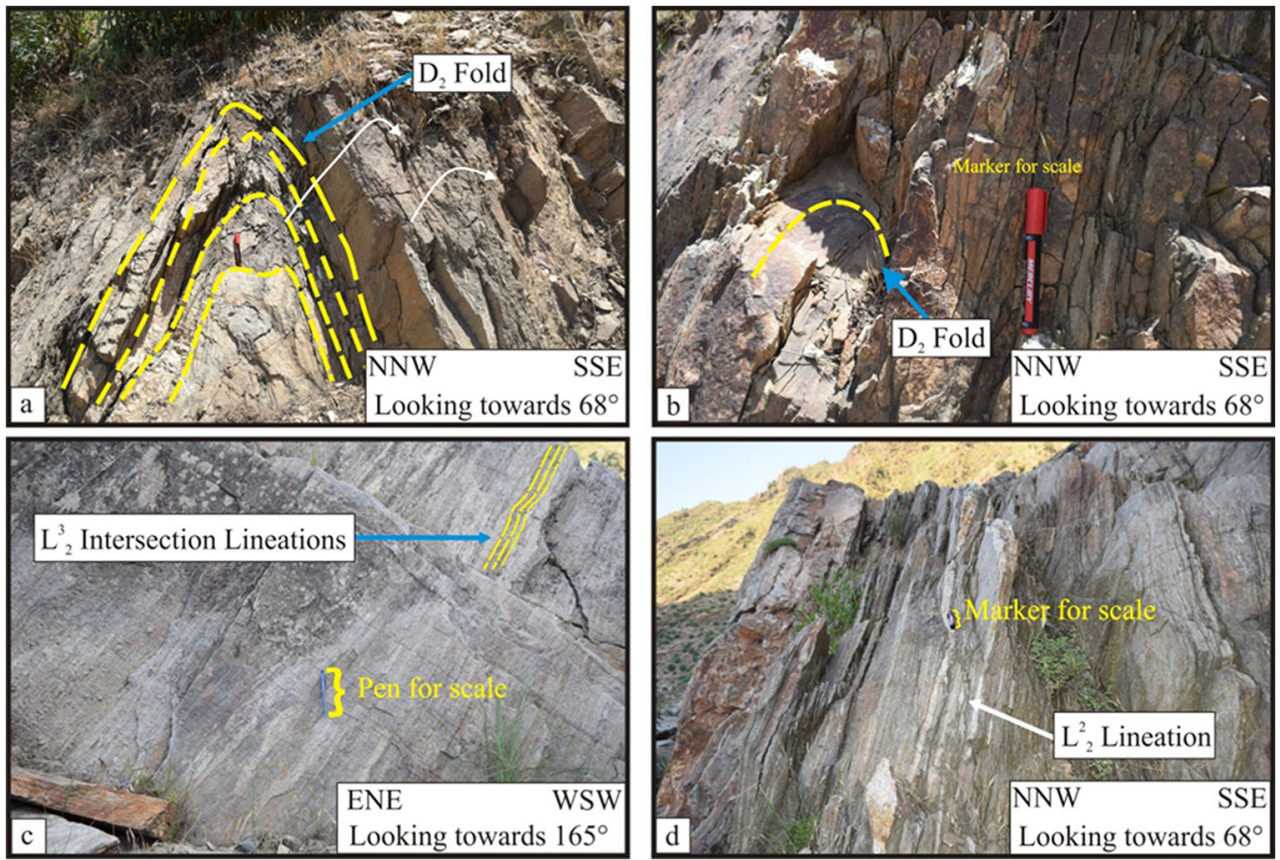
Fig. 6 a Equal area lowerhemisphere stereo plots showing orientations of ENE-WSW trending main $\mathrm{S}_{2}$ foliation. The white dots represent poles to the great circles; $\mathbf{b}$ equal area lowerhemisphere stereo pots of $\mathrm{L}_{2}^{3}$ intersection lineations; $\mathbf{c}$ equal area rose diagram showing orientation of ENE-WSW trending $\mathrm{L}_{2}{ }_{2}$ lineations
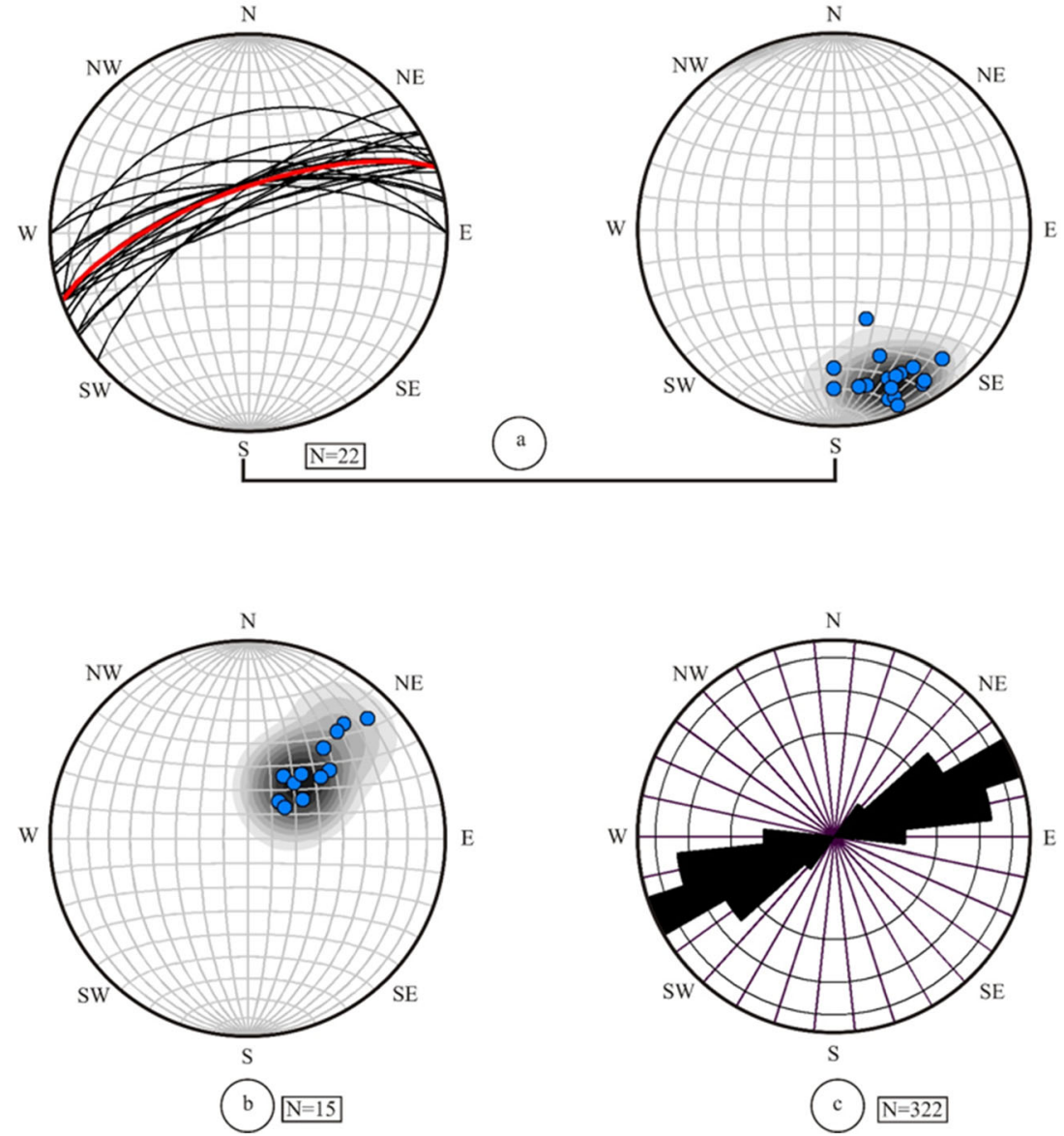

(c) $\mathrm{N}=322$ was not observed mesoscopically. To look into the impact of penetrative fabrics on the strength of rocks the selected bulk samples are cored perpendicular and parallel to the main $\mathrm{S}_{2}$ foliations. Microscopically, the $\mathrm{S}_{2}$ crenulation cleavage/Cfabric microlithon nicely preserved $S_{1}$ crenulated cleavage and is defined by sigmoidal muscovite, biotite, and stretched quartz (Fig. 2a-c). Microscopic differential stresses anastomose the well-developed matrix $\mathrm{S}_{2}$ around coarse-grained plagioclase and feldspar grains (Fig. 3b, c). $S_{2}$ intensification around rigid plagioclase and feldspar grains at strain caps led to precipitation of quartz and fine mica in the strain shadows (Fig. $3 \mathrm{c}, \mathrm{d})$. The $\mathrm{S}_{2}$ crenulation cleavage also deflects around sigmoid to lenticular mica fish trending $22.21^{\circ}$ with top-to-SSE shear sense (Fig. 7; Table 2).

The UCS average value of four core samples that were taken parallel to the main $\mathrm{S}_{2}$ tectonic fabric from the CGG is $51.8 \mathrm{MPa}$ as compare to UCS average value of $45.35 \mathrm{MPa}$ obtained from the core samples taken perpendicular to the $\mathrm{S}_{2}$ main foliation. The UCS values of amphibolite rock from the KIA are 91.31 MPa and 59.23 MPa parallel and perpendicular to the $S_{2}$ main foliations, respectively (Table 3). The S2 sample obtained from comparatively massive part of the CGG shows less variation in strength in core samples cut parallel and perpendicular to the $S_{2}$ foliations and lineations. The
$\mathrm{UCS}, c$, and $\tau$ values are higher in the core samples that were cut parallel to the pervasive $\mathrm{S}_{2}$ and $\mathrm{L}_{2}^{2}$ because the parallel shear stress on the sigmoidal crenulated cleavages in the microlithon of the $S_{2}$ and layer parallel top-to-SSE shear sense on $\mathrm{S}_{2}$ mica fish with a mean value of $22.21^{\circ}$ counterbalances the parallel applied load (Fig. 9).The UCS differs from sample to sample due to difference in tectonically induced penetrative planar and linear fabrics. The strength of selected core samples varies with orientation of the tectonically induced fabric. The $\mathrm{S}_{1}$ crenulated cleavage, ENE-WSW trending $\mathrm{S}_{2}$ main foliation, $\mathrm{D}_{2}$ mesoscopic folds, $\mathrm{L}_{2}^{2}$ lineations, petrography, preferred oriented sigmoidal grains, and mica fish have implication for the overall in-situ engineering constructions and tunnels that will be built on the northernmost Indian plate rocks, Indus Suture Zone, and southernmost rocks of the KIA.

Non-coaxial dextral shear sense on strongly preferred oriented sigmoidal grains (plagioclase and feldspar) that formed by crystal-plastic deformation and mica fish enhances foliation parallel strength of the CGG rocks (Figs. $3 \mathrm{a}-\mathrm{d}$ and $7 \mathrm{a}-\mathrm{f}$ ). However, the UCS values decrease in the core samples that were cut perpendicular to the pervasive $\mathrm{S}_{2}$ and $\mathrm{L}_{2}^{2}$ because the perpendicular shear on the sigmoidal crenulated cleavages in the microlithon of the $S_{2}$ and $S_{2}$ mica fish enhances the applied load, which lead to the failure of core samples (Fig. 9). 
Fig. 7 a Single composite mica fish (XPL); $\mathbf{b}$ mineral fish of feldspar (XPL); $\mathbf{c}$ internal mica fish (XPL); $\mathbf{d}$ sigmoid foliation mica fish (XPL); e large sigmoidal mica fish (XPL); f small numbers of mica fish present in crenulation cleavage (XPL). Note that $\mathrm{S}_{2}$ deflects around different type of mica fish. Thin sections a, $\mathrm{b}, \mathrm{d}$ and $\mathrm{c}, \mathrm{e}, \mathrm{f}$ are cut parallel and perpendicular to ENE-WSW trending $S_{2}$ respectively
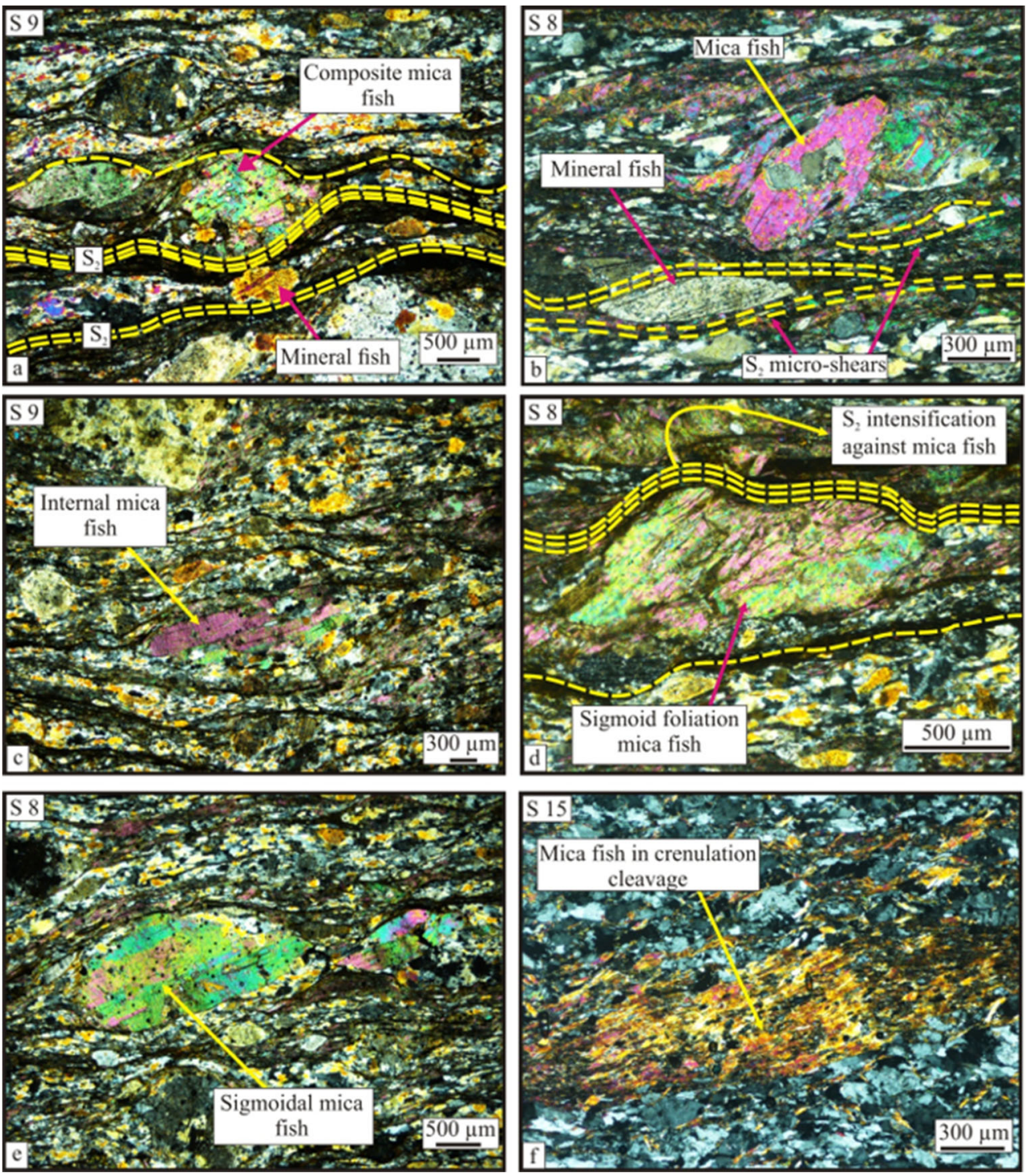

Table 2 Average values of all the measured angles of mica fish

\begin{tabular}{ll}
\hline Thin sections & Average angle of mica fish $\left(^{\circ}\right)$ \\
\hline 6 & 23.33 \\
7 & 24.73 \\
8 & 21 \\
9 & 22.13 \\
10 & 23.61 \\
11 & 23.28 \\
12 & 18.22 \\
13 & 20 \\
15 & 21.18 \\
16 & 24.64 \\
Overall average & 22.21 \\
\hline
\end{tabular}

The lower UTS values were observed in the core samples, which were cut parallel to the main $\mathrm{S}_{2}$ foliation and $\mathrm{L}_{2}^{2}$ lineation compared with the core samples cut perpendicular to the tectonic fabric (Table 3; Fig. 9). Core samples obtained parallel and perpendicular to $\mathrm{D}_{2}$ associated ENE-WSW axial plane $\mathrm{S}_{2}$ foliations show variable UCS and UTS values, respectively. The $\mathrm{S}_{2}$ parallel core samples have higher UCS, $c$, $\tau$, and UTS values than those cut perpendicular to the $S_{2}$ main fabric (Table 3).

\section{Discussion}

Tectonically induced structures including foliations, lineations, mineral alignments, mineral alteration, metamorphic textures, and veins at microscopic to mesoscopic scales 

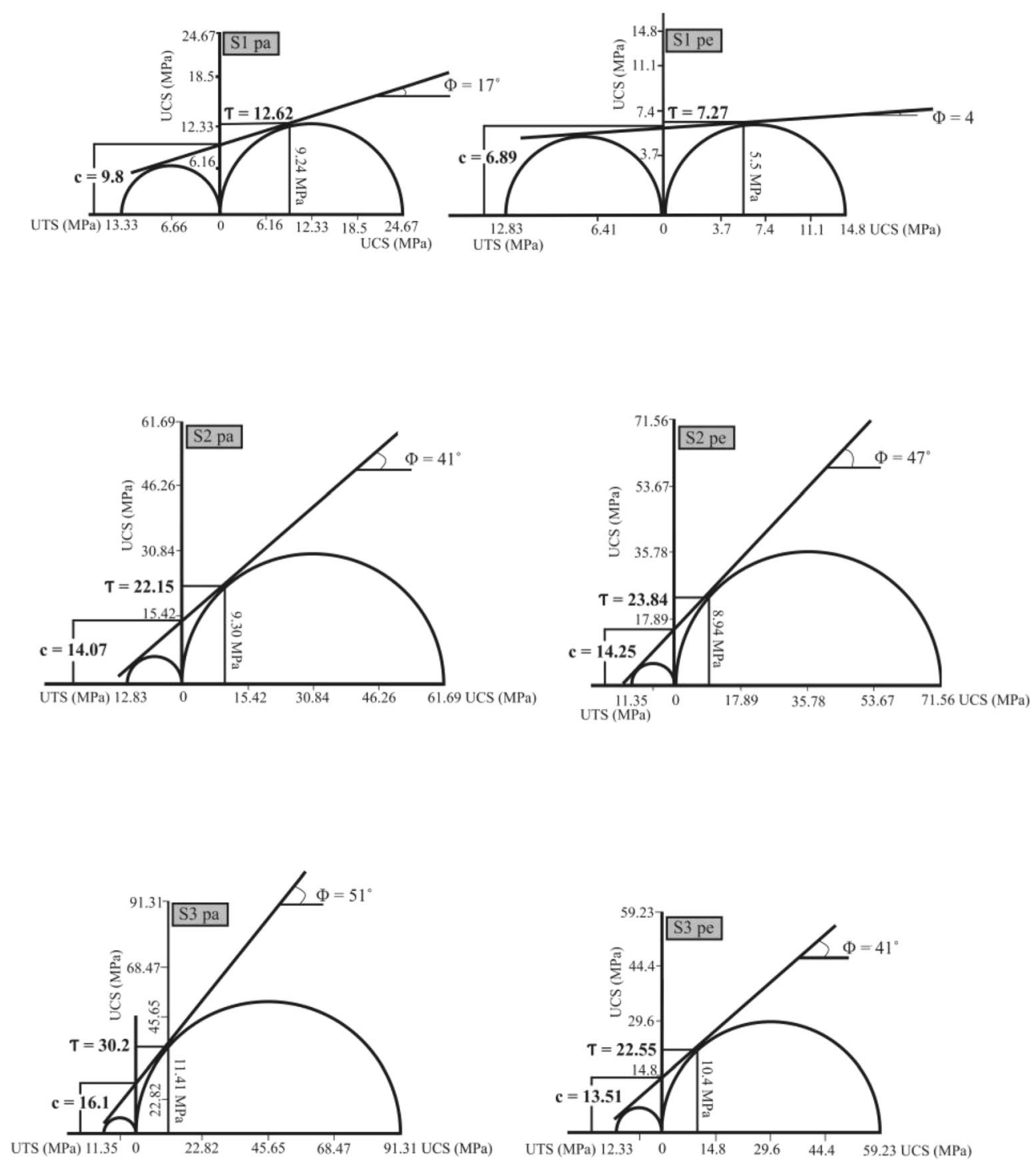

Fig. 8 Mohr's circle diagrams of shear strength measured for all parallel (pa) and perpendicular (pe) core samples using UCS and UTS values. UCS and UTS values are plotted against positive and negative $X$-axes, respectively. $c$ and $\tau$ values are plotted on $Y$-axis

significantly affect geomechanical properties of tectonized rocks (Ramamurthy et al. 1993; Singh et al. 2012; Ozbek et al. 2018). Genetic complexity in the form of penetrative foliations and lineations makes geomechanical behavior of metamorphic rocks unpredictable (Behrestaghi et al. 1996). According to Everall and Sanislav (2018) tectonically deformed rocks dominantly fail by reactivation of pre-existing planes of weakness that include foliations, fractures, and veins. The above arguments imply that each rock should be analyzed independently for anisotropies because the UCS is significantly reduced in the presence of pre-existing weaknesses developed during multiple tectonic events. In general, affects of penetrative fabrics on geomechanical properties of anisotropic rocks are mostly looked at microscopic to mesoscopic observations without assessing the overprinting fabrics. However, in the current study multiple penetrative foliations that have significantly affected geomechanical properties of rocks collected south of the MMT would have most likely been studied without looking at the affect of strongly preferred oriented sigmoidal porphyroblasts, mica fish, and crenulated cleavages in the microlithon of the main $\mathrm{S}_{2}$. The UCS and UTS values differ from sample to sample due to variably induced penetrative fabrics (Table 3 ). The orientation of mica fish, sigmoidal porphyroblasts, and crenulated cleavages to the applied load directly affected the strength of rocks. The UCS significantly increased in the $\mathrm{S}_{2}$ parallel core samples containing mica fish and $\mathrm{S}_{1}$ crenulated cleavages in the microlithon by opposing the applied load as result of load parallel shear at the main matrix crenulation cleavage (Fig. 9). Mica fish and $S_{1}$ in the microlithon of the $\mathrm{S}_{2}$ that respectively counterbalanced and facilitated the applied load in foliation parallel and perpendicular core samples would not be detectable without a detailed petrographic analyses. Therefore, the main differential stresses that are 

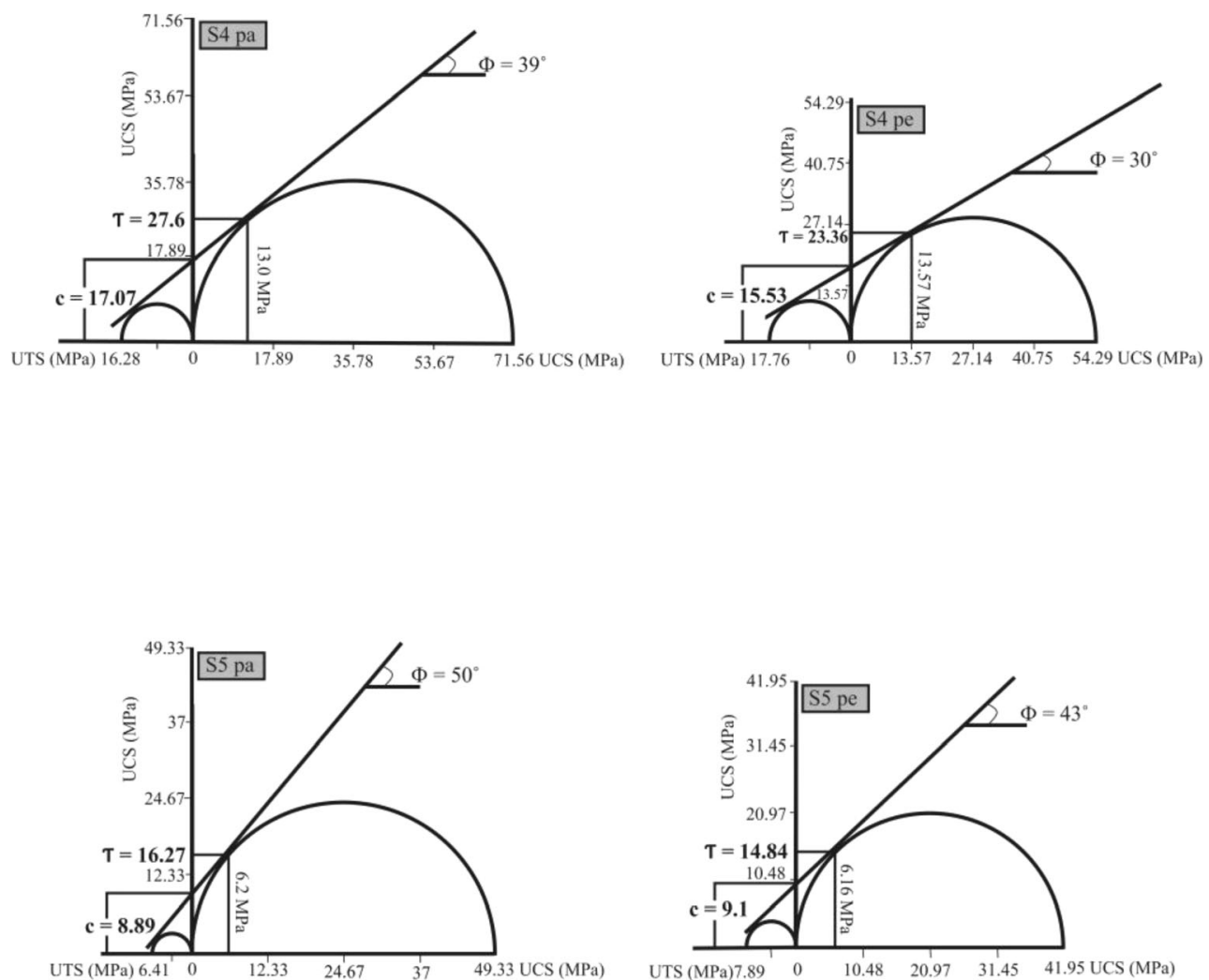

Fig. 8 continued.

preserved in rocks in the form of simple or complex foliations and lineations must be determined before the use of tectonites in any engineering constructions or as aggregates.

\section{Conclusions}

- This study displays some more complicated behavior of multiple deformed rocks under very simple load conditions, which need to be assessed under load and numerical simulation models.

- It is observed that microscopic pervasive crenulation and crenulated cleavage intersection planes and mica fish could potentially induce layer parallel slips that remain perpendicular or parallel to the applied stresses.

- Pervasive slip layers parallel to the applied stresses enhance the strength of tectonically deformed rocks. However, the same planes when perpendicular to the applied stresses decrement the strength of these rocks. The
Table 3 UCS, UTS, $c, \tau$, and $\varphi$ values of core samples cut parallel and perpendicular to the main $\mathrm{S}_{2}$ foliation. Foliation parallel cores are characterized by the higher values as compared to foliation perpendicular cores

\begin{tabular}{llllll}
\hline Sample & $\begin{array}{l}\text { UCS } \\
(\mathrm{MPa})\end{array}$ & $\begin{array}{l}\text { UTS } \\
(\mathrm{MPa})\end{array}$ & $\begin{array}{l}\text { Shear strength }(\tau) \\
\mathrm{MPa})\end{array}$ & $\begin{array}{l}\text { Cohesion }(c ; \\
\mathrm{MPa})\end{array}$ & $\begin{array}{l}\text { Angle of internal friction } \\
(\Phi)\left({ }^{\circ}\right)\end{array}$ \\
\hline 1-parallel (CGG) & 24.67 & 13.33 & 12.62 & 9.8 & 17 \\
1-perpendicular & 14.8 & 12.83 & 7.27 & 6.89 & 4 \\
2-parallel (CGG) & 61.69 & 12.83 & 22.15 & 14.07 & 41 \\
2-perpendicular & 71.56 & 11.35 & 23.84 & 14.25 & 47 \\
4-parallel (CGG) & 71.56 & 16.28 & 27.6 & 17.07 & 39 \\
4-perpendicular & 54.29 & 17.76 & 23.36 & 15.5 & 30 \\
5-parallel (CGG) & 49.35 & 6.41 & 16.27 & 8.8 & 50 \\
5-perpendicular & 41.95 & 7.89 & 14.84 & 9.1 & 43 \\
3-parallel & 91.31 & 11.35 & 30.2 & 16.1 & 51 \\
$\quad$ (amphibolite) & & 12.33 & 22.55 & 13.51 & 41 \\
3-perpendicular & 59.23 & 12.5 & & \\
\hline
\end{tabular}


Fig. 9 Schematic diagram showing effect of the crenulated cleavage preserved in the microlithon of the well-developed $\mathrm{S}_{2}$ crenulation cleavage on the UCS of a rock (see text for detail)

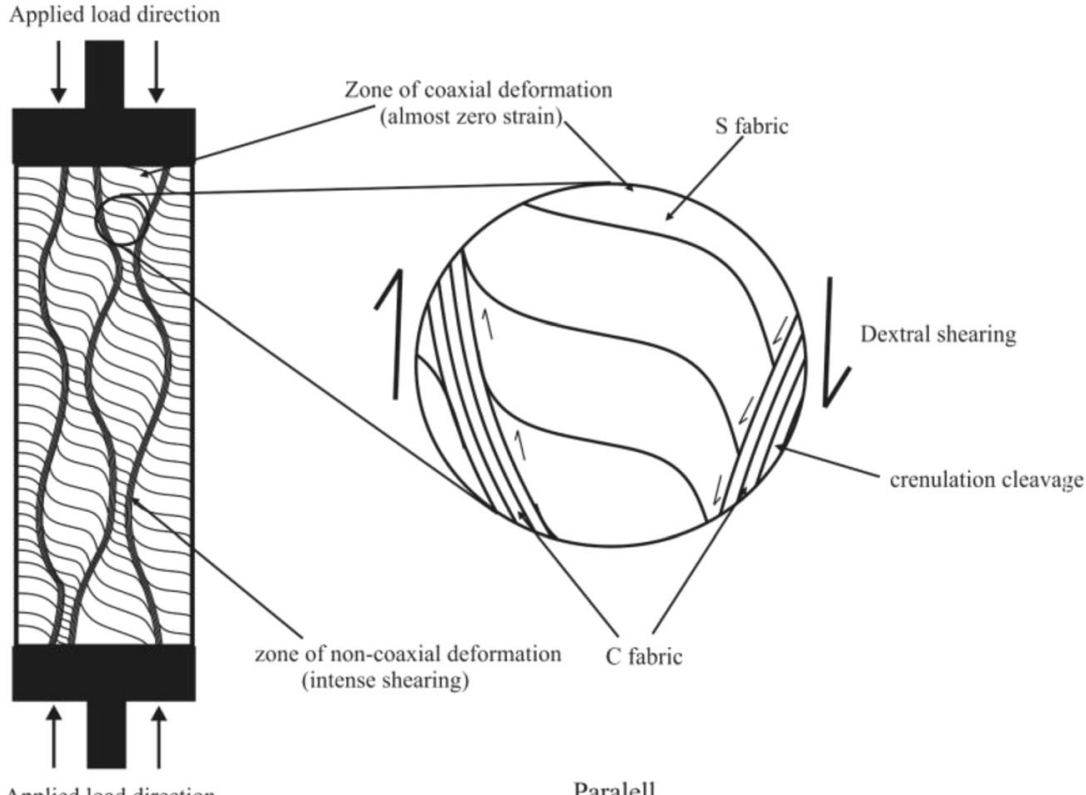

Applied load direction

Paralell

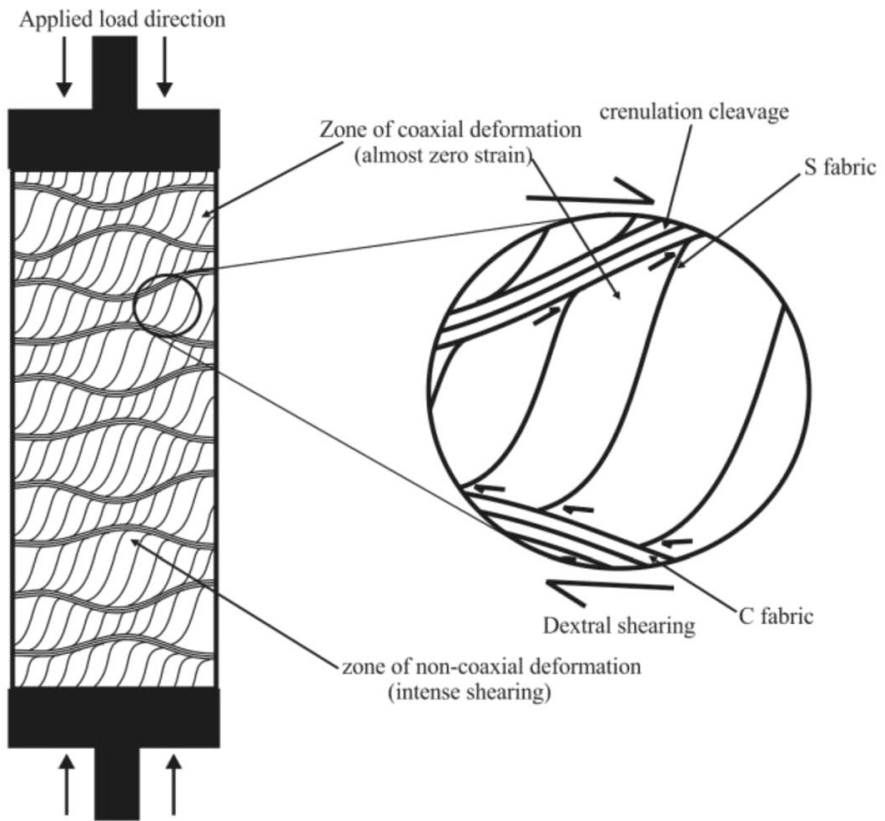

Applied load direction
Perpendicular
USC is respectively increased or decreased by reactivation of mica fish and $\mathrm{S}_{1}$ crenulated cleavage parallel and perpendicular to the applied load.

Acknowledgments We appreciate the thin section preparation and petrographic facilities of the same department. We are thankful for sample coring at the Department of Mining Engineering, University of Engineering and Technology Peshawar.

Funding information The authors received financial and logistics supports from the Department of Geology, University of Peshawar.
Open Access This article is licensed under a Creative Commons Attribution 4.0 International License, which permits use, sharing, adaptation, distribution and reproduction in any medium or format, as long as you give appropriate credit to the original author(s) and the source, provide a link to the Creative Commons licence, and indicate if changes were made. The images or other third party material in this article are included in the article's Creative Commons licence, unless indicated otherwise in a credit line to the material. If material is not included in the article's Creative Commons licence and your intended use is not permitted by statutory regulation or exceeds the permitted use, you will need to obtain permission directly from the copyright holder. To view a copy of this licence, visit http://creativecommons.org/licenses/by/4.0/. 


\section{References}

Ali A, Habib U, Rehman AU, Zada N, Abidin ZU, Ismail M (2016) Tectonic imprints of the Hazara Kashmir Syntaxis on the Mesozoic rocks exposed in Munda, Mohmand agency northwest of Pakistan. Acta Geol Sin Engl 90(2):440-445

ASTM D-3967 (1986) Standard test method for splitting tensile strength of intact rock core specimens. Annual Book of ASTM Standards Philadelphia, Pennsylvania

ASTM D-3976 (1986) Standard test method for splitting tensile strength of intact rock core specimens. American society for testing material, Philadelphia

ASTM D-7012 (2010) Compressive strength and elastic moduli of intact rock core specimens under varying states of stress and temperatures. Annual Book of ASTM Standards, West Conshohocken, PA

Barton N, Quadros E (2015) Anisotropy is everywhere, to see, to measure and to model. Rock Mech Rock Eng 48:1323-1339

Behrestaghi MHN, Rao KS, Ramamurthy T (1996) Engineering geological and geotechnical responses of schistose rocks from dam project areas in India. Eng Geol 44(1-4):183-201

Chamine HI, Afonso MJ, Teixeira J et al (2013) Using engineering geosciences mapping and GIS-based tools for georesources management: lessons learned from rock quarrying. Eur Geol Mag J Eur Fed Geol 36:27-33

DiPietro JA, Pogue KR (2004) Tectonostratigraphic subdivisions of the Himalaya: a view from the west. Tectonics 23:271-297

DiPietro JA, Ahmad I, Hussain A (2008) Cenozoic kinematic history of the Kohistan fault in the Pakistan Himalaya. Geol Soc Am Bull 120: $1428-1440$

Duan K, Kwok CY (2015) Discrete element modeling of anisotropic rock under Brazilian test conditions. Int J Rock Mech Min Sci 78:46-56

Everall TJ, Sanislav IV (2018) The influence of pre-existing deformation and alteration textures on rock strength, failure modes and shear strength parameters. Geosci 8:124-138

Hudson JA, Cosgrove JW (1997) Integrated structural geology and engineering rock mechanics approach to site characterization. Int J Rock Mech Min Sci 34(3/4):136.1-136.15

Hudson JA, Harrison JP (1997) Engineering rock mechanics - an introduction to the principles, 1st edn. Pergamon, Oxford
Kazmi AH, Jan MQ (1997) Geology and tectonics of Pakistan. Graphic Publishers, Karachi

Lister GL, Snoke AW (1984) S-C mylonites. J Struct Geol 6:617-638

Milnes AG (2006) Understanding brittle deformation at the Olkiluoto site- literature compilation for site characterization and geological modeling. Working Report 2006-25

Milnes AG, Hudson JA, Wikstrom L, Aaltonen I (2006) Foliation: geological background, rock mechanics significance, and preliminary investigations at Olkiluoto. Posiva working report, pp 2006-03

Miskovsky K, Taborda Duarte M, Kou SQ, Lindqvist PA (2004) Influence of the mineralogical composition and textural properties on the quality of coarse aggregates. J Mater Eng Perform 13:144150

Ozbek A, Gul M, Karacan E, Alca O (2018) Anisotropy effect on strengths of metamorphic rocks. J Rock Mech Geotech Eng 10: 164-175

Passchier CW, Trouw RAJ (2005) Microtectonics. Springer-Verlag, Berlin Heidelberg New York

Priest SD (1993) Discontinuity analysis for rock engineering. Chapman \& Hall, London

Punturo R, Cirrincione R, Fazio E, Fiannacca P (2014) Microstructural, compositional and petrophysical properties of mylonitic granodiorites from an extensional shear zone (Rhodope Core complex, Greece). Geol Mag 151(6):1051-1071

Ramamurthy T, Venkatappa RG, Singh J (1993) Engineering behaviour of phyllites. Eng Geol 33(3):209-225

Singh TN, Kainthola A, Venkatesh A (2012) Correlation between point load index and uniaxial compressive strength for different rock types. Rock Mech Rock Eng 45(2):259-264

Ten Grotenhuis SM, Trouw RAJ, Passchier CW (2003) Evolution of mica fish in mylonitic rocks. Tectonophysics 372:1-21

Watkins H, Bond CE, Healy D, Butler RWH (2015) Appraisal of fracture sampling methods and a new workflow to characterize heterogeneous fracture networks at outcrop. J Struct Geol 72:67-82

Whitney DL, Evans BW (2010) Abbreviations for names of rock-forming minerals. Am Mineral 95:185-187

Yin A (2006) Cenozoic tectonic evolution of the Himalayan orogen as constrained by along-strike variation of structural geometry, exhumation history, and foreland sedimentation. Earth-Sci Rev 76:1-131 